\section{SQZ Biotech's main squeeze}

\section{By Michael J. Haas, Associate Editor}

SQZ Biotechnologies Co. has boosted its coffers with 2 awards totaling more than $\$ 300,000$ for its CellSqueeze technology, a microfluidics-based platform that can deliver different bioactive materials directly into cells. The awards add to the company's $\$ 1$ million in seed funding and the revenue it generates from academic clients and industrial partners, and they will help fund SQZ's own R\&D.

According to Armon Sharei, SQZ cofounder and chairman and CellSqueeze co-inventor, "We now have 40 academic and industrial partners that are using the CellSqueeze platform and providing us with revenue."

Among them are the Massachusetts Institute of Technology (MIT), Harvard University, the Ragon Institute of MGH, MIT and Harvard, Goethe University Frankfurt and supply and service company Promega Corp.

Sharei is a postdoctoral fellow in the research group of Ulrich von Andrian, who is a professor of microbiology and immunology at Harvard Medical School and program leader in basic immunology at Ragon.

CellSqueeze utilizes microfluidics chips containing 80 parallel channels, each of which has at least one constriction point that is narrower than the diameter of a cell. The process of squeezing past the constriction point opens transient pores in the cell membrane, which creates an opportunity to introduce molecules into the cell.

In the past two years, SQZ's founders and collaborators at MIT and other institutions have shown that CellSqueeze can introduce a diverse range of compounds-including small molecules, polysaccharides, siRNA, proteins, carbon nanotubes and quantum dots-into immune cells, embryonic stem cells (ESCs) and nine other cell types without adversely affecting cell viability. ${ }^{1-4}$

Last month, SQZ won the $\$ 100,000$ grand prize in the annual startup competition sponsored by Boston-based accelerator MassChallenge. Additionally, The Boeing Co. and the Center for the Advancement of Science in Space (CASIS) awarded the company the CASIS-Boeing Prize for Technology in Space-worth more than \$200,000-to support the use of CellSqueeze on the International Space Station (ISS). Details of the ISS project are undisclosed.

Back on Earth, SQZ is pursuing the utility of the platform in academia, industry and its own R\&D programs.
"On the academic side there is a lot of interest in getting peptides, proteins, antibodies, nanoparticles and other materials into cells to see what happens," Sharei told SciBX. The ability of CellSqueeze to help probe intracellular processes "is a step change in research tools and has gotten us a lot of attention from academia," he added.

He said that the company provides the platform to "select clients whose needs are not well met by current transfection technologies" rather than offering it broadly on a fee-for-service basis.

Sharei said that several of SQZ's academic clients in cancer and infectious disease research are using the platform in immunological and live cell imaging applications for intracellular delivery of materials such as proteins into cell types like primary immune cells that other technologies cannot readily achieve.

The primary use of CellSqueeze in industry is in high throughput screening. "Pharmas screen large libraries of compounds, but the cell-based assays involved only give a yes-or-no readoutthey don't tell you whether the compound actually got inside the cell," Sharei said.

Using CellSqueeze for intracellular delivery of small molecules and probes in a high throughput screen can allow a more representative comparison between results from the screen and results from the cell-free biochemical assays in which many compounds are first tested, he said. He added, "Our technology can provide more insight into the molecular mechanisms of active compounds, improve target validation capabilities and ultimately improve the quality of hits in the high throughput screens."

Long term, SQZ aims to apply CellSqueeze to in-house development of cell-based immunotherapies_-such as engineered chimeric antigen receptor (CAR) T cells and autologous or allogeneic cell transplants- to treat a range of diseases. The revenue stream from academia and industry has enabled the company to contribute resources toward that goal, Sharei said.

"The current prototype of CellSqueeze can handle one million cells per second, which has been sufficient for our preclinical experiments and a good starting point for scaling up the technology for high throughput screening and human cell studies," he said. Given the company's experience with optimizing previous versions of the technology, "it will not be too difficult to improve its capacity by tenfold or even a hundredfold within a few months."

Cofounder and CEO Agustin Lopez Marquez told SciBX that the company holds exclusive rights from MIT for any application of the CellSqueeze platform - thus giving SQZ a wide playing field for the technology.

Haas, M.J. SciBX 7(44); doi:10.1038/scibx.2014.1284

Published Nov. 13, 2014

\section{REFERENCES}

1. Adamo, A. et al. Anal. Chem. 84, 6438-6443 (2012)

2. Lee, J. et al. Nano Lett. 12, 6322-6327 (2012)

3. Sharei, A. et al. Proc. Natl. Acad. Sci. USA 110, 2082-2087 (2013)

4. Sharei, A. et al. Integr. Biol. (Camb.) 6, 470-475 (2014) 


\section{ANALYSIS}

COMPANIES AND INSTITUTIONS MENTIONED

The Boeing Co. (NYSE:BA), Chicago, III.

Center for the Advancement of Science in Space, Melbourne,

Fla.

Goethe University Frankfurt, Frankfurt, Germany

Harvard Medical School, Boston, Mass.
Harvard University, Cambridge, Mass.

Massachusetts Institute of Technology, Cambridge, Mass.

MassChallenge, Boston, Mass.

Promega Corp., Madison, Wisc.

Ragon Institute of MGH, MIT and Harvard, Cambridge, Mass. SQZ Biotechnologies Co., Boston, Mass. 